\title{
Cryptococcal Meningitis in A Patient With Giant Cell Arteritis
}

\author{
Jin LV, ${ }^{1}$ Qiankun ZHANG ${ }^{2}$ \\ ${ }^{1}$ Department of Neurology, Lishui People's Hospital, Lishui, China \\ ${ }^{2}$ Department of Rheumatology, Lishui Central Hospital, Lishui, China
}

\begin{abstract}
Cryptococcal meningitis is a rare complication of giant cell vasculitis. Because its manifestations are very similar to those of giant cell vasculitis relapse, the diagnosis is often delayed and/or misdiagnosed. In this article, we present the case of a 65-year-old female patient who suffered from cryptococcal meningitis during high-dose steroid therapy for giant cell vasculitis.

Keywords: Cryptococcal meningitis; giant cell vasculitis; glucocorticoids.
\end{abstract}

Giant cell arteritis (GCA) is the most common vasculitis of the elderly, primarily affecting individuals over 50 years of age. The incidence increases with age, peaking around the age of 80 years. ${ }^{1,2}$ High-dose glucocorticoids are the first-line treatment for GCA and their use may be prolonged. Consequently, the majority of patients experience glucocorticoid-related side effects. ${ }^{2}$ Severe infections and infection-related mortality are increased during the first year after the diagnosis of GCA. ${ }^{3}$ Cryptococcosis is a fungal infection caused by Cryptococcus neoformans, and is generally associated with immunodeficiency and immunosuppressive agents. Cryptococcosis often involves the central nervous system and is rarely reported in GCA. GCA mainly presents as headache and fever and can be associated with stroke, ${ }^{4,5}$ so, when complicated by cryptococcal meningitis, the diagnosis is often delayed. In this article, we present the case of a 65-year-old female patient with GCA who presented with cryptococcal meningitis.

\section{CASE REPORT}

A 65-year-old female patient was admitted to the hospital because of persistent headache and fever $\left(37.5-39^{\circ} \mathrm{C}\right)$ of five days duration. She had a history of GCA six years ago and relapsed four months prior to admission. According to our diagnostic work-up, the patient did not have any diseases other than GCA. A written informed consent was obtained from the patient.

Six years ago, the patient was admitted with fever, headache, and transient vision loss. Laboratory findings indicated erythrocyte sedimentation rate of $110 \mathrm{~mm} /$ hour (normal 0-20 $\mathrm{mm} /$ hour) and C-reactive protein of $100 \mathrm{mg} / \mathrm{L}$ (normal $<5 \mathrm{mg} / \mathrm{L}$ ), while the cerebrospinal fluid (CSF) analysis and cranial magnetic resonance imaging were normal. To further clarify the diagnosis, a temporal artery biopsy was performed, and the results confirmed the GCA diagnosis (Figure 1). She was treated with prednisone and azathioprine for about six

Received: February 25, 2017 Accepted: March 06, 2017 Published online: April 04, 2017

Correspondence: Qiankun Zhang, MD. Department of Rheumatology, Lishui Central Hospital, 323000 Lishui, China.

Tel: +86-578-2681234 e-mail: qk011007@126.com

@2017 Turkish League Against Rheumatism. All rights reserved. 


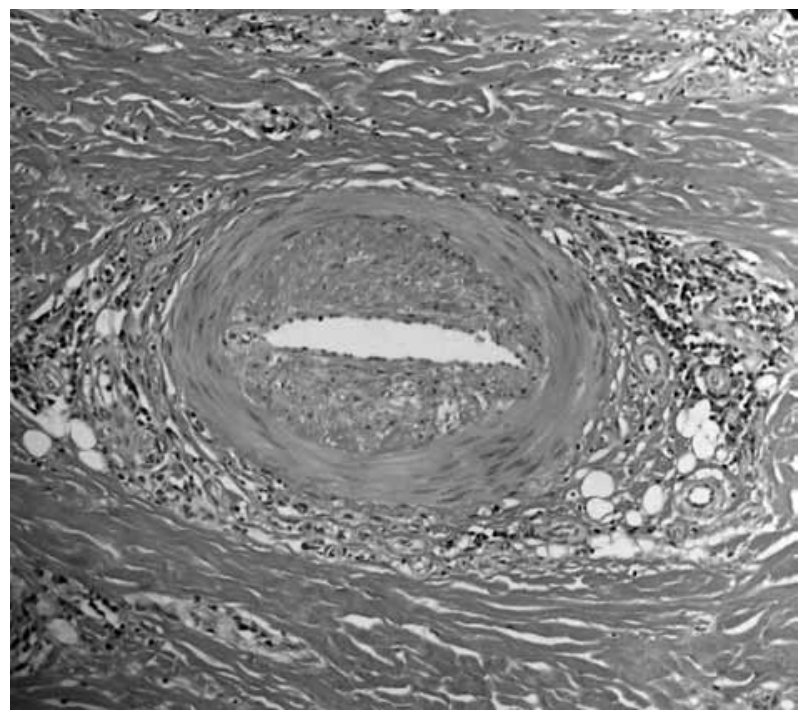

Figure 1. Temporal artery biopsy showing mononuclear cell infiltration $(\mathrm{H}-\mathrm{E} \times 200)$.

months. Over the past four years, she did not have any uncomfortable symptoms or receive any drugs.

Four months ago, she relapsed with fatigue, fever, and headache. She was treated with $60 \mathrm{mg}$ prednisone per day and showed improvement in her symptoms of headache and fatigue. Her prednisone dosage was reduced to $25 \mathrm{mg}$ per day and azathioprine $50 \mathrm{mg}$ per day when in hospital at this time.

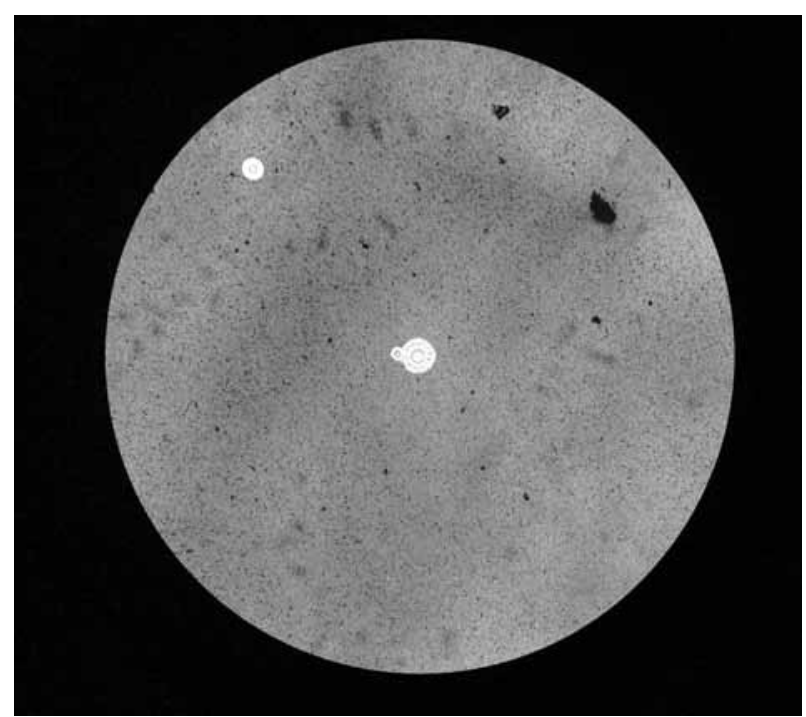

Figure 2. Cerebrospinal fluid analysis showing positive India ink staining for cryptococcus ( $\times 400$ magnification).
On admission, the patient was febrile $\left(38.5^{\circ} \mathrm{C}\right)$ and had a moderate headache. Examination was remarkable for neck stiffness and bilateral papilledema. General physical, neurological, and systemic examinations were normal. Laboratory findingswere as follows: erythrocyte sedimentation rate of $120 \mathrm{~mm} /$ hour (normal $0-20 \mathrm{~mm} /$ hour), C-reactive protein level of $125 \mathrm{mg} / \mathrm{L}$ (normal $<5 \mathrm{mg} / \mathrm{L}$ ), white blood cell count of $8.8 \times 10^{9} / \mathrm{L}$ (normal $4 \times 10^{9}-10 \times 10^{9} / \mathrm{L}$ ) with normal differential count, hemoglobin level of $10.4 \mathrm{~g} / \mathrm{dL}$ (normal $12-16 \mathrm{~g} / \mathrm{dL}$ ), platelet count of $560 \times 10^{9} / \mathrm{L}$ (normal $100 \times 10^{9}-300 \times 10^{9} / \mathrm{L}$ ), and fibrinogen level of $8.2 \mathrm{~g} / \mathrm{L}$ (normal $<4.3 \mathrm{~g} / \mathrm{L}$ ). Other biochemical findings including a test for human immunodeficiency virus were negative or within the reference limits. Computed tomography of the thorax and abdominal ultrasound showed normal findings. Microbiological analysis of urine and multiple blood samples yielded sterile findings. Sternal puncture findings were normal. Laboratory tests for systemic or malignant diseases were negative or within the normal range. CSF analysis showed that India ink staining was positive for cryptococcus (Figure 2). CSF pressure was $22 \mathrm{~cm} \mathrm{H} \mathrm{H}_{2} \mathrm{O}$, and contained 10 cells $/ \mu \mathrm{L}$, all lymphocytes, elevated protein $(2.38 \mathrm{~g} / \mathrm{L})$, low glucose $(31 \mathrm{mg} / \mathrm{dL}), \mathrm{CSF} /$ serum glucose ratio $=0.14$, and adenosine deaminase of 7 IU/L. The cranial magnetic resonance imaging was unremarkable (Figure 3). Azathioprine was

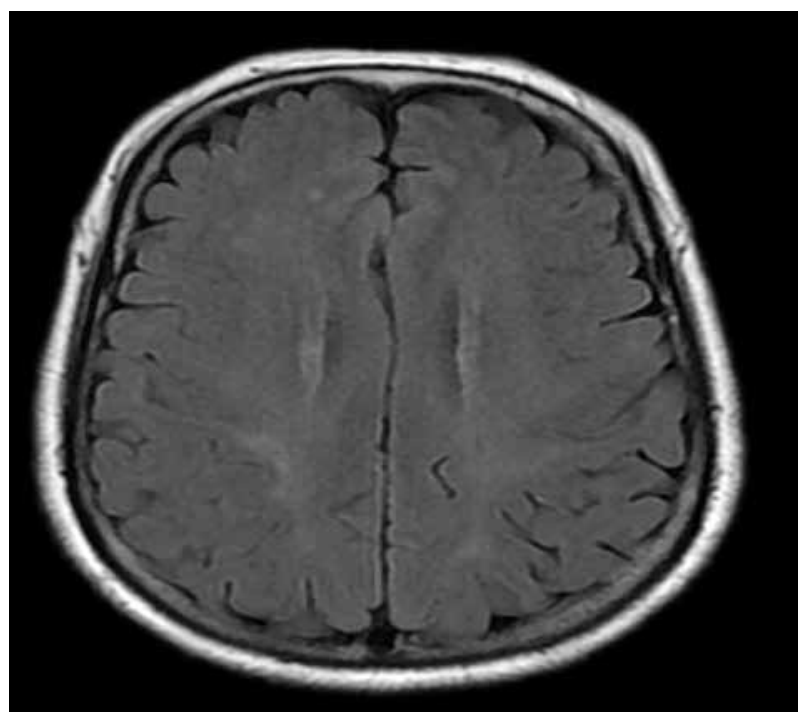

Figure 3. Cranial magnetic resonance imaging was normal. 
suspended, prednisone was tapered off to $10 \mathrm{mg}$ per day, and amphotericin B and 5-flucytosine were introduced for six weeks. Clinical response was good. There were no neurological sequelae or relapse after 20 months of follow-up.

\section{DISCUSSION}

Giant cell arteritis is the most common primary vasculitis, ${ }^{6}$ predominantly affecting older individuals. Common manifestations include headache, fever, morning stiffness and pain in the shoulder and/or hip girdle, ischemic stroke, visual disturbance, and/or permanent vision loss. GCA often requires high and sometimes sustained corticosteroid therapy to prevent the development of sight-threatening complications. ${ }^{7}$ Nearly half of the patients experience relapses during the tapering of glucocorticoids and recurrence on glucocorticoid withdrawal. ${ }^{8,9}$ In these patients, glucocorticoid therapy can rapidly lead to infectious complications, mainly with opportunistic pathogens.

Our patient's presenting symptoms were persistent headache and fever, later followed by vomiting. The diagnosis of this patient was cryptococcal meningitis with features of elevated intracranial pressure and the differential diagnosis included GCA relapse and other septic meningitis. Any intracranial space-occupying lesion was excluded by the normal brain imaging.

Various opportunistic infections have been reported in patients with GCA, including invasive aspergillosis, nocardiosis, tuberculosis, varicellazoster infection, and pneumocystis pneumonia. ${ }^{10-12}$ However, C. neoformans infection has seldom been reported. Hedderwick et al. ${ }^{11}$ reported that a 77-year-old GCA patient was admitted to hospital with dyspnea and culture of bronchoalveolar fluid yielded C. neoformans. Revest et al. ${ }^{13}$ reported four cases of cryptococcal infection (three meningitis) in patients whose immunosuppression was related to chronic lymphocytic leukemia, giant cell temporal arteritis, gastric neoplasm and lupus, respectively.

Giant cell arteritis patients appear to be at risk for opportunistic infections for at least three possible reasons. First, the most important of these risk factors is the use of high-dose long-term corticosteroids. Owing to immunosuppression, treatment-related infections are common and represent an important cause of early mortality. ${ }^{14,15}$ Second, most reports have included patients over 65 years of age, and aging has been shown to decrease both cellular immunity and humoral immunity in humans. ${ }^{16,17}$ Third, the presence of GCA itself may increase susceptibility to infection through macrophage and $T$ cell activation leading to dysregulation of the immune system. ${ }^{18,19}$

The older adult may also present with atypical manifestations of meningitis, although cryptococcal meningitis in GCA patients has rarely been reported. When patients have a headache with corticosteroids usage, cryptococcal meningitis should be considered and excluded.

\section{Declaration of conflicting interests}

The authors declared no conflicts of interest with respect to the authorship and/or publication of this article.

\section{Funding}

The authors received no financial support for the research and/or authorship of this article.

\section{REFERENCES}

1. Borchers AT, Gershwin ME. Giant cell arteritis: a review of classification, pathophysiology, geoepidemiology and treatment. Autoimmun Rev 2012;11:544-54.

2. Dunstan E, Lester SL, Rischmueller M, Dodd T, Black $\mathrm{R}$, Ahern $\mathrm{M}$, et al. Epidemiology of biopsy-proven giant cell arteritis in South Australia. Intern Med J 2014;44:32-9.

3. Schmidt J, Smail A, Roche B, Gay P, Salle V, Pellet $\mathrm{H}$, et al. Incidence of Severe Infections and InfectionRelated Mortality During the Course of Giant Cell Arteritis: A Multicenter, Prospective, Double-Cohort Study. Arthritis Rheumatol 2016;68:1477-82.

4. Calamia KT, Hunder GG. Giant cell arteritis (temporal arteritis) presenting as fever of undetermined origin. Arthritis Rheum 1981;24:1414-8.

5. Samson M, Jacquin A, Audia S, Daubail B, Devilliers $\mathrm{H}$, Petrella $\mathrm{T}$, et al. Stroke associated with giant cell arteritis: a population-based study. J Neurol Neurosurg Psychiatry 2015;86:216-21.

6. Muratore F, Pazzola G, Pipitone N, Boiardi L, Salvarani C. Large-vessel involvement in giant cell arteritis and polymyalgia rheumatica. Clin Exp Rheumatol 2014;32:106-11.

7. Matteson EL, Gold KN, Bloch DA, Hunder GG. Long-term survival of patients with giant cell arteritis 
in the American College of Rheumatology giant cell arteritis classification criteria cohort. Am J Med 1996;100:193-6.

8. Martinez-Lado L, Calviño-Díaz C, Piñeiro A, Dierssen T, Vazquez-Rodriguez TR, Miranda-Filloy JA, et al. Relapses and recurrences in giant cell arteritis: a population-based study of patients with biopsyproven disease from northwestern Spain. Medicine (Baltimore) 2011;90:186-93.

9. Proven A, Gabriel SE, Orces C, O'Fallon WM, Hunder GG. Glucocorticoid therapy in giant cell arteritis: duration and adverse outcomes. Arthritis Rheum 2003;49:703-8.

10. Berger CT, Greiff V, John S, Koenig KF, Bigler $\mathrm{MB}$, Recher M, et al. Risk factors for pneumocystis pneumonia in giant cell arteritis: a single-centre cohort study. Clin Exp Rheumatol 2015;33:122-5.

11. Hedderwick SA, Bonilla HF, Bradley SF, Kauffman CA. Opportunistic infections in patients with temporal arteritis treated with corticosteroids. J Am Geriatr Soc 1997;45:334-7.

12. Sendi P, Wolf A, Graber P, Zimmerli W. Multiple opportunistic infections after high-dose steroid therapy for giant cell arteritis in a patient previously treated with a purine analog. Scand J Infect Dis 2006;38:922-4.

13. Revest M, Decaux O, Frouget T, Cazalets C, Albert JD, Chevrier S, et al. Cryptococcal infections in non-
HIV infected patients. Study of four cases and review of literature. Rev Med Interne 2006;27:203-8.

14. Ninan J, Nguyen AM, Cole A, Rischmueller M, Dodd $\mathrm{T}$, Roberts-Thomson $\mathrm{P}$, et al. Mortality in patients with biopsy-proven giant cell arteritis: a south australian population-based study. J Rheumatol 2011;38:2215-7.

15. Fabiani S, Bruschi F. Rheumatological patients undergoing immunosuppressive treatments and parasitic diseases: a review of the literature of clinical cases and perspectives to screen and follow-up active and latent chronic infections. Clin Exp Rheumatol 2014;32:587-96.

16. Stervbo U, Bozzetti C, Baron U, Jürchott K, Meier S, Mälzer JN, et al. Effects of aging on human leukocytes (part II): immunophenotyping of adaptive immune B and T cell subsets. Age (Dordr) 2015;37:93.

17. Ginaldi L, De Martinis M, Modesti M, Loreto F, Corsi MP, Quaglino D. Immunophenotypical changes of T lymphocytes in the elderly. Gerontology 2000;46:242-8.

18. Weyand CM, Hicok KC, Hunder GG, Goronzy JJ. Tissue cytokine patterns in patients with polymyalgia rheumatica and giant cell arteritis. Ann Intern Med 1994;121:484-91.

19. Weyand CM, Ma-Krupa W, Goronzy JJ. Immunopathways in giant cell arteritis and polymyalgia rheumatica. Autoimmun Rev 2004;3:46-53. 